\title{
Monoclonal antibody L26: an antibody that is reactive with normal and neoplastic B lymphocytes in routinely fixed and paraffin wax embedded tissues
}

\author{
A J NORTON, P G ISAACSON \\ From the Department of Histopathology, University College and Middlesex Medical School, London
}

SUMMARY Formalin fixed and paraffin wax embedded tissue from 85 well characterised cases of non-Hodgkin's lymphoma and Hodgkin's disease were studied using the avidin-biotin-peroxidase complex technique. Among the non-Hodgkin's lymphomas all cases of B cell lymphoma were reactive with $\mathrm{L} 26$, a monoclonal antibody which is as yet an unclustered pan B cell reagent, with the exception of pre-B cell acute lymphoblastic leukaemia and malignant lymphoma plasmacytic. Eighteen well characterised cases of T cell lymphoma, selected to include tumours previously shown to exhibit cross reactivity with antibodies to fixation resistant B cell related antigens, were similarly studied. Neoplastic cells in all but one case were unstained by L26. Twenty seven cases of Hodgkin's disease were also examined. In five cases all Reed-Sternberg cells and their variants were strongly stained by L26; only a proportion of Reed-Sternberg cells and their variants were recognised in a further five cases.

Monoclonal antibody L26 promises to be a valuable reagent for the diagnosis of malignant lymphoma in routinely fixed and paraffin wax embedded tissues. Its advantage lies in its sensitivity and greater B cell specificity than any of the B cell related reagents currently available for the study of malignant lymphoma in fixed tissues.

Until recently the immunophenotypic characterisation of malignant lymphoma has relied on the immunocytochemical demonstration of leucocyte antigens in cryostat sections of fresh frozen tissue. An increasing range of novel monoclonal antibodies, however, is now available, which facilitate the diagnosis of malignant lymphoma in formalin fixed and paraffin wax embedded tissues. Several of these novel antibodies recognise $B$ cell related antigens that are resistant to fixation. Most bind to lineage restricted epitopes on the leucocyte common molecule, ${ }^{1-3}$ while others identify antigens, which although not wholly restricted to leucocytes, indicate a B cell lineage in known lymphoid tissues. ${ }^{45}$ Anti-HLA$D^{67}$ and antibodies to HLA-DR-like moieties ${ }^{4}$ have been used to assign a $B$ cell phenotype but these are unreliable, especially in the diagnosis of large cell lymphomas which may express class II antigens

Accepted for publication 18 June 1987 independent of their phenotype. Despite the number of antibodies available there is a considerable degree of cross lineage reactivity, particularly among the leucocyte common restricted group, necessitating the use of extensive antibody panels to avoid assigning erroneous phenotypes to cases of lymphoma. ${ }^{8-10}$

Monoclonal antibody L26 identifies mature B lymphocytes. ${ }^{1113}$ Although submitted to the second and third leucocyte typing workshops, L26 is as yet unclustered. In sodium dodecyl sulphatepolyacrylamide gel electrophoresis $\mathrm{L} 26$ precipitates an antigen with a major $33 \mathrm{kd}$ molecular weight component, together with a minor $30 \mathrm{kd}$ component. ${ }^{12}$ Unlike other B cell restricted leucocyte antibodies, L26 recognises an epitope which is resistant to conventional formalin fixation. In this study we evaluated $\mathbf{L} 26$ on a panel of malignant lymphomas fixed in formalin and embedded in paraffin wax and contrasted its reactivity with that obtained using other antibodies to $B$ cell related antigens resistant to fixation. 


\section{Material and methods}

Formalin fixed and paraffin wax embedded tissue from 85 cases of Hodgkin's disease and nonHodgkin's lymphoma were obtained from the surgical pathology files of the department of histopathology of this hospital. The 40 cases of B cell lymphoma were classified according to the Kiel classification $^{15}$; 18 cases of $T$ cell lymphoma were categorised by the scheme of Stansfeld ${ }^{17}$; and 27 cases of Hodgkin's disease were classified by the scheme of Lukes and Butler. ${ }^{16}$ All but five of the cases of nonHodgkin's lymphoma had previously been characterised in frozen sections using a panel of monoclonal antibodies. In five cases of B cell lymphoma (two cases of malignant lymphoma plasmacytic, two cases of malignant lymphoma centroblastic, one case of Burkitt's lymphoma) immunoglobulin light chain restriction had been shown in paraffin sections.

Normal tonsils from routine tonsillectomies and non-specific reactive lymph nodes were also studied to evaluate L26 staining in normal tissue and to assess immunoreactivity after different fixation protocols.

\section{ANTIBODY AND SPECIFICITY}

L26 was provided as a mouse ascitic fluid by Dakopatts: the production and initial characterisation of L26 has been detailed elsewhere. ${ }^{1112}$ The properties and cellular distribution of L26 antigen were reported in the second and third international workshops on leucocyte antigens. ${ }^{1318}$

\section{IMMUNOPEROXIDASE TECHNIQUE}

Paraffin sections were cut at 3-4 $\mu \mathrm{m}$ and stained by a modification of the avidin-biotin-peroxidase complex method described by Guesdon et al. ${ }^{19}$ Briefly, sections were deparaffinised and taken to industrial methylated spirit. Endogenous peroxidase was blocked with $\mathrm{H}_{2} \mathrm{O}_{2}$ in methanol. Sections were then washed in running tap water and placed in Tris buffered saline (TBS) at $\mathrm{pH} \mathrm{7.6.} \mathrm{Primary} \mathrm{antibody}$ at an optimal dilution of $1 / 50000$ (determined by checkerboard titration) was then applied for 30 minutes. Sections were then rewashed in TBS. The bridge antibody, biotinylated rabbit antimouse (Dakopatts), incorporating 1/25 normal human serum (to block cross reactivity) was then applied for

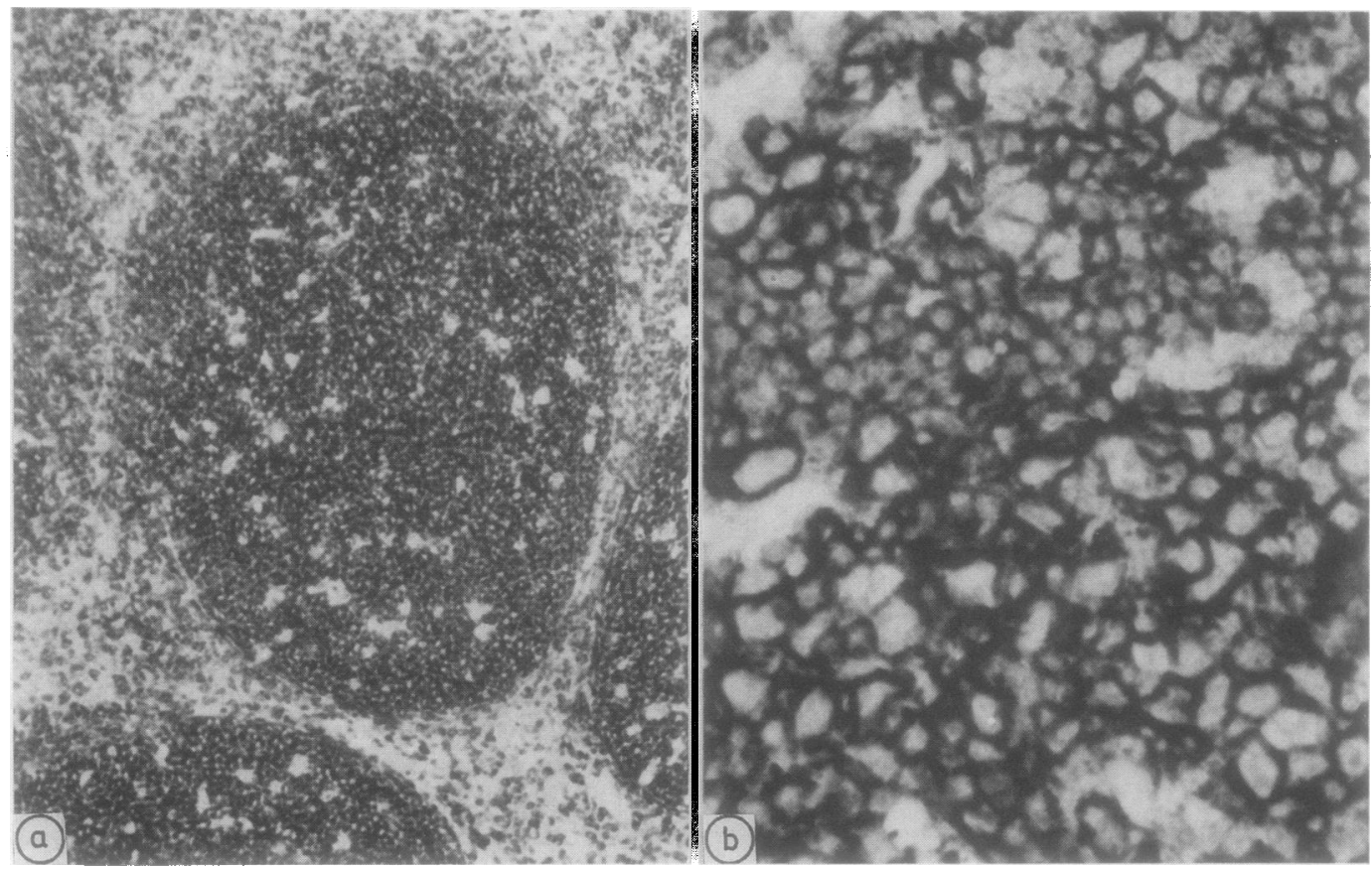

Fig la Low power view of normal tonsil stained with L26. Clear staining of surface membrane of B cells within follicles together with scattered $B$ blasts in interfollicular areas is seen. (Immunoperoxidase.)

Fig lb High power view from edge of one of the reactive follicles seen in fig la. Strong surface membrane staining is seen both on follicle centre cells and the smaller mantle zone cells. Denser staining in follicle centres is due to immunoreactivity with the processes of follicular dendritic reticulum cells. (Immunoperoxidase.) 
Table 1 Details of 40 B cell lymphomas studied showing their reactivity with MTI

\begin{tabular}{|c|c|c|c|}
\hline \multirow[b]{2}{*}{ Lymphoma type } & \multirow[b]{2}{*}{ Total No of cases } & \multicolumn{2}{|c|}{ No of cases reactive with: } \\
\hline & & $\overline{M T 1}$ & L26 \\
\hline $\begin{array}{l}\text { Malignant lymphoma lymphoblastic (CALL) } \\
\text { Malignant lymphoma lymphoblastic } \\
\text { African Burkitt's lymphoma } \\
\text { Malignant lymphoma lymphocytic } \\
\text { Malignant lymphoma prolymphocytic } \\
\text { Hairy cell leukaemia } \\
\text { Malignant lymphoma lymphoplasmocytic } \\
\text { Malignant lymphoma centrocytic } \\
\text { Malignant lymphoma centroblastic } \\
\text { Malignant lymphoma immunoblastic } \\
\text { Malignant lymphoma centroblastic/centrocytic follicular } \\
\text { Malignant lymphoma centroblastic/centrocytic diffuse } \\
\text { Malignant lymphoma plasmacytic } \\
\text { Sclerosing mediastinal B cell lymphoma }\end{array}$ & $\begin{array}{l}1 \\
2 \\
1 \\
4 \\
1 \\
1 \\
1 \\
5 \\
6 \\
5 \\
5 \\
5 \\
2 \\
1\end{array}$ & $\begin{array}{l}1 \\
2 \\
0 \\
3 \\
1 \\
0 \\
0 \\
2 \\
1 \\
1 \\
0 \\
0\end{array}$ & $\begin{array}{l}0 \\
2 \\
1 \\
4 \\
1 \\
1 \\
1 * \\
5 \\
6 \\
5 \\
5 \dagger \\
5 \\
0 \\
1\end{array}$ \\
\hline
\end{tabular}

*Cells with pronounced plasmacytic differentiation unstained.

$\nmid$ Neoplastic cells and follicular dendritic reticulum cells stained.

30 minutes. Sections were washed in TBS, and avidinbiotin-peroxidase complex (Dakopatts) applied for 30 minutes. A further wash in TBS was followed by developing in diaminobenzidine for five to 10 minutes, counterstaining with Mayer's haematoxylin, and mounting. Negative controls, both with and without irrelevant primary antiserum, were run in parallel.

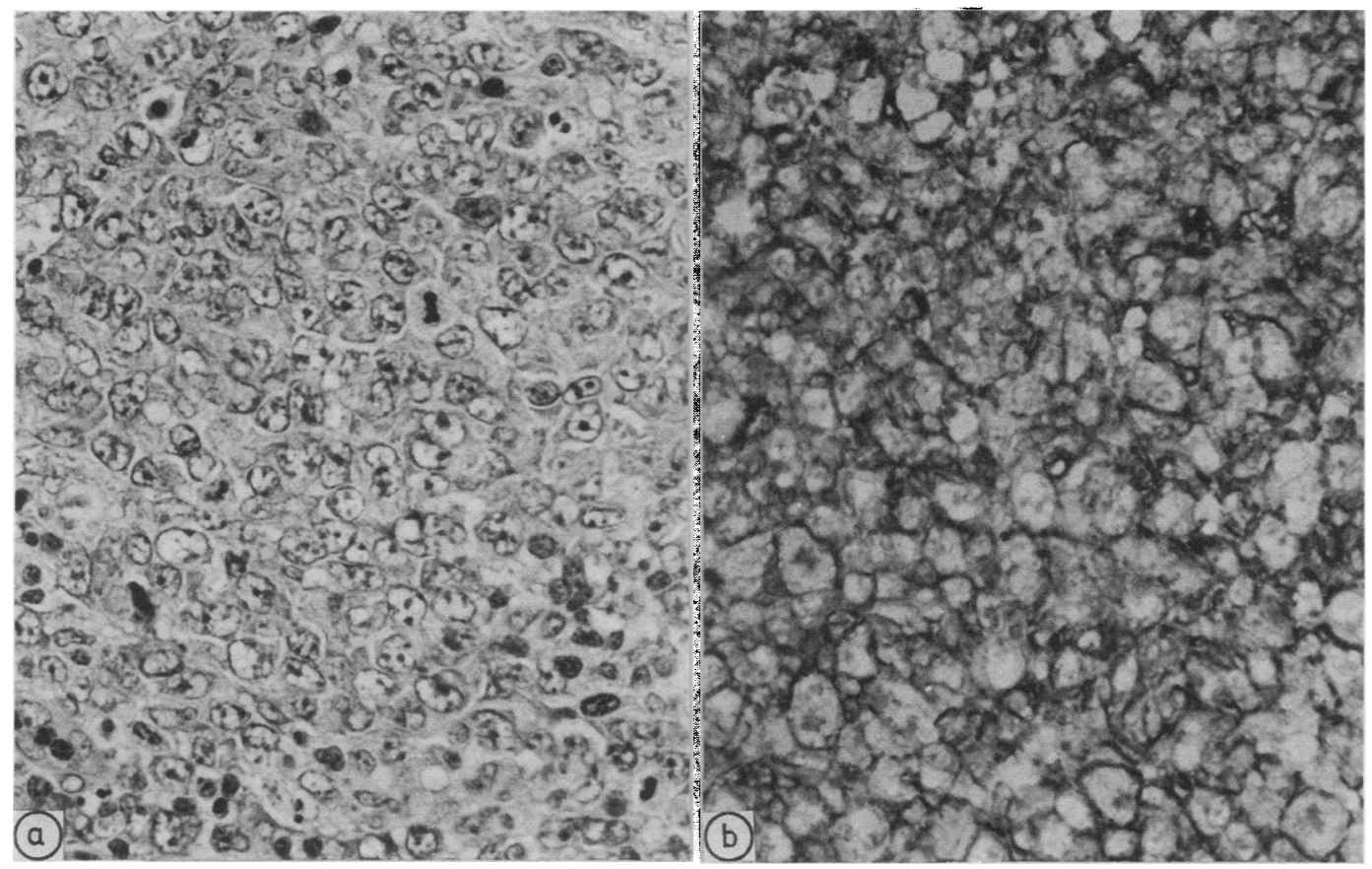

Fig 2a Malignant lymphoma centroblastic showing a sheet of large blast cells with open nuclei and multiple small nucleoli, some of which are continuous with the nuclear membrane. (Haematoxylin and eosin.)

Fig 2b Same tumour as in fig 2a stained with L26. Strong surface membrane staining of all neoplastic cells is seen. (Immunoperoxidase.) 


\section{Results}

Surface membrane staining of B lymphocytes and follicular dendritic reticulocyte cells was clearly shown on paraffin sections of tonsil (fig 1 ) and reactive lymph node using L26. Interfollicular B blasts were also recognised, but $T$ cells, macrophages, and plasma cells were unstained. Excellent staining results were obtained in routinely processed tissue fixed in Bouin's fluid, neutral buffered formol saline, acid formalin ( $2 \%$ acetic acid in $4 \%$ formalin), and unbuffered formol saline. Weak but definite staining of B lymphocytes was obtained in tissues decalcified overnight in acetic acid. Trypsinisation abolished all staining with this reagent.

\section{MALIGNANT LYMPHOMA \\ $B$ cell lymphoma}

Staining results obtained with $\mathrm{L} 26$ on the panel of 40 B cell lymphomas are detailed in table 1 . Reactivity of these cases with the $T$ cell restricted antibody MT1 are also given. ${ }^{10}$ Uniformly strong surface membrane staining was seen in all of the lymphomas studied (fig
2), with the exception of the case of common acute lymphoblastic leukaemia (CALL) and both cases of malignant lymphoma plasmacytic. Neoplastic cells showing extreme plasmacytic differentiation in the case of malignant lymphoma lymphoplasmacytic were also unstained. In all cases of malignant lymphoma centroblastic/centrocytic $(\mathrm{CB} / \mathrm{CC})$ follicular, and in tumours where entrapped residual benign follicle centres were present, some staining of the follicular dendritic reticulum cell network was observed (fig 3).

\section{$T$ cell lymphoma}

The panel of $18 \mathrm{~T}$ cell lymphomas selected for study was deliberately biased to include cases known to be immunoreactive with other B cell related antibodies in routinely processed tissue. ${ }^{9}$ The details of these tumours, their observed cross reactivities, and staining results with L26 are given in table 2 . Small reactive B lymphocytes were recognised by $L 26$ in all cases of $T$ cell lymphoma and the prominent reactive follicle centres in the cases of $\mathrm{T}$ zone lymphoma were highlighted. With the exception of one case, the neo-

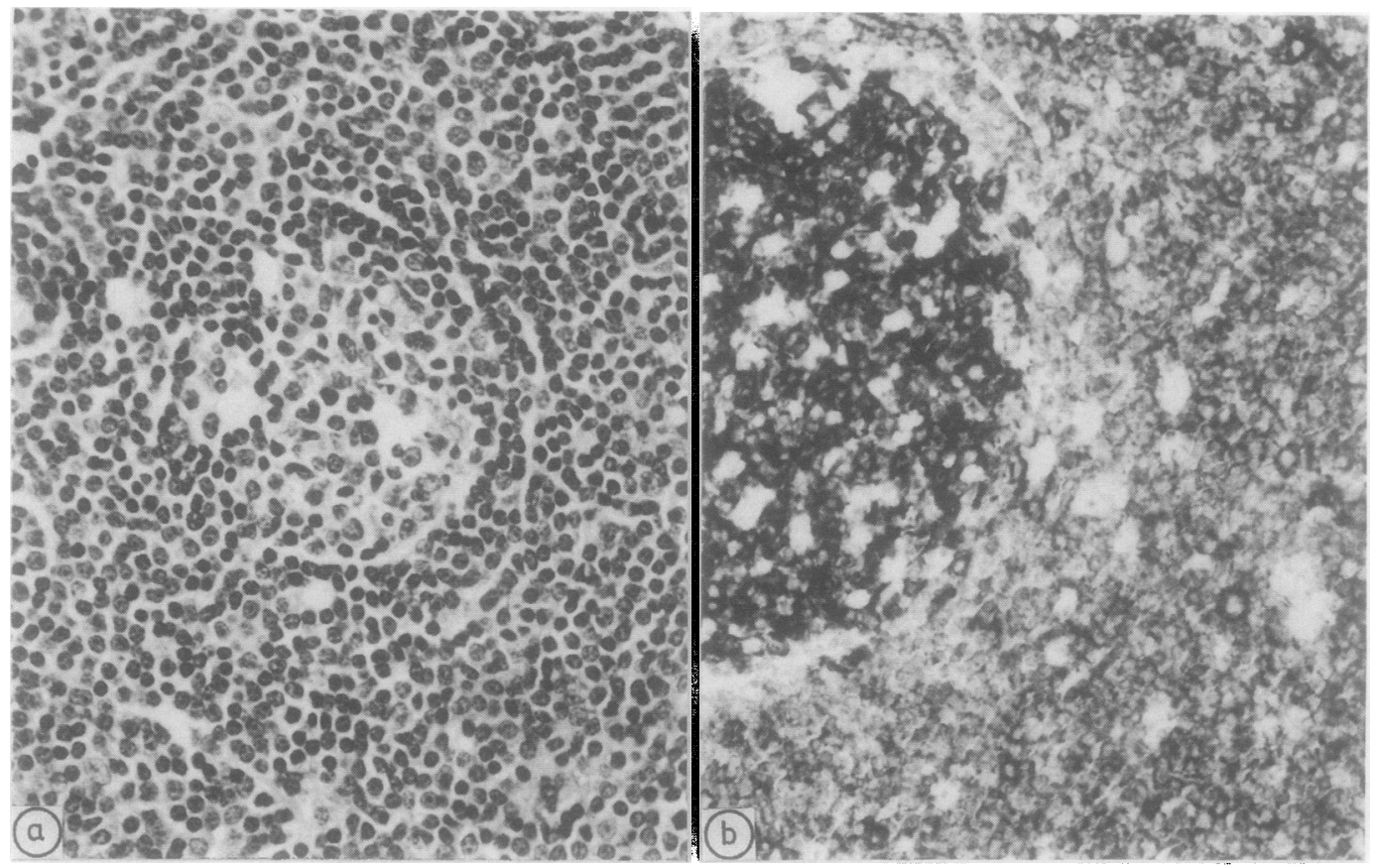

Fig 3a Malignant lymphoma lymphocytic (B-CLL) infiltrating lymph node. Sheet of small lymphocytes is seen encircling trapped benign follicle centre. (Haematoxylin and eosin.)

Fig 3b Same tumour as in fig 3a stained with L26. Sheet of neoplastic small lymphocytes is strongly stained. Reactive follicle centre shows intense staining, with highlighting of both follicle centre blasts and meshwork of follicular dendritic reticulum cells. (Immunoperoxidase.) 
Table 2 Details of 18 T cell lymphomas studied

\begin{tabular}{|c|c|c|c|}
\hline Lymphoma type & $\begin{array}{l}\text { Case } \\
\text { No }\end{array}$ & $\begin{array}{l}\text { Cross } \\
\text { reactivity }\end{array}$ & $\begin{array}{l}\text { Reactivity } \\
\text { with L26 }\end{array}$ \\
\hline Lymphoblastic & $\begin{array}{l}1 \\
2\end{array}$ & $\begin{array}{l}\text { None } \\
\text { None }\end{array}$ & - \\
\hline Monomorphic small cell & 3 & None & - \\
\hline Monomorphic large cell & $\begin{array}{l}4 \\
5\end{array}$ & $\begin{array}{l}\text { None } \\
\text { MB2, LN2 }\end{array}$ & - \\
\hline \multirow{2}{*}{$\begin{array}{l}\text { Angioimmunoblastic } \\
\text { lymphadenopathy-like }\end{array}$} & & & \\
\hline & $\begin{array}{l}6 \\
7 \\
8\end{array}$ & $\begin{array}{l}\text { None } \\
\text { MB1 } \\
\text { MB1, LN2 }\end{array}$ & $\begin{array}{l}- \\
-\end{array}$ \\
\hline T zone lymphoma & $\begin{array}{r}9 \\
10\end{array}$ & $\begin{array}{l}\text { None } \\
\text { MB1, LN2 }\end{array}$ & - \\
\hline Lennert's lymphoma & 11 & None & - \\
\hline $\begin{array}{l}\text { Pleomorphic, mixed } \\
\text { Medium/large cell }\end{array}$ & $\begin{array}{l}12 \\
13\end{array}$ & $\begin{array}{l}\text { MB1, LN2 } \\
\text { MB1, MT2, } \\
\text { CD45R*, KiB3, } \\
\text { LN2 }\end{array}$ & - \\
\hline \multirow[t]{2}{*}{ Pleomorphic large cell } & $\begin{array}{l}14 \\
15\end{array}$ & $\begin{array}{l}\text { LN2 } \\
\text { MB1, MT2, CD45R, } \\
\text { KiB3 }\end{array}$ & - \\
\hline & 16 & None & - \\
\hline Pleomorphic large cell & 17 & MB1, LN2 & - \\
\hline (MHI type $\dagger$ ) & 18 & CD45R, KiB3, LN2 & - \\
\hline
\end{tabular}

*CD45R antigen detected using MAb 4KB5.

†Malignant histiocytosis of the intestine/coeliac associated lymphoma.
Table 3 Details of 27 cases of Hodgkin's disease using L26 in routinely fixed and paraffin wax embedded tissues

\begin{tabular}{lrll}
\hline & & $\begin{array}{l}\text { No of cases } \\
\text { reactive with L26 }\end{array}$ \\
\hline $\begin{array}{l}\text { Lymphocyte and histiocyte } \\
\text { predominant }\end{array}$ & 2 & & \\
$\begin{array}{l}\text { Mixed cellularity } \\
\text { Nodular sclerosing }\end{array}$ & 12 & $2^{*}$ & \\
Lymphocyte depleted & 12 & $2^{*}$ & $4 \dagger$ \\
& 1 & 0 & $1 \dagger$ \\
\hline
\end{tabular}

*All Reed-Sternberg cells and their variants stained.

tLess than $50 \%$ of Reed-Sternberg and their variants stained.

plastic cells in all these tumours were unstained by L26. The single exception was notable for cross reactivity with a range of antibodies effective in routinely processed tissue, including $\mathrm{MB} 1, \mathrm{KiB} 3, \mathrm{MT} 2$, and 4KB5 (CD45R). In frozen section this tumour had a clear T cell phenotype (CD2, CD3, CD5, CD7 and CD8), and genetic studies had shown clonal $T$ cell receptor $\beta$ chain gene rearrangement, and a germ line configuration for the immunglobulin heavy chain $\mathbf{J}_{\mathbf{H}}$ variable region (case $13^{20}$ ).
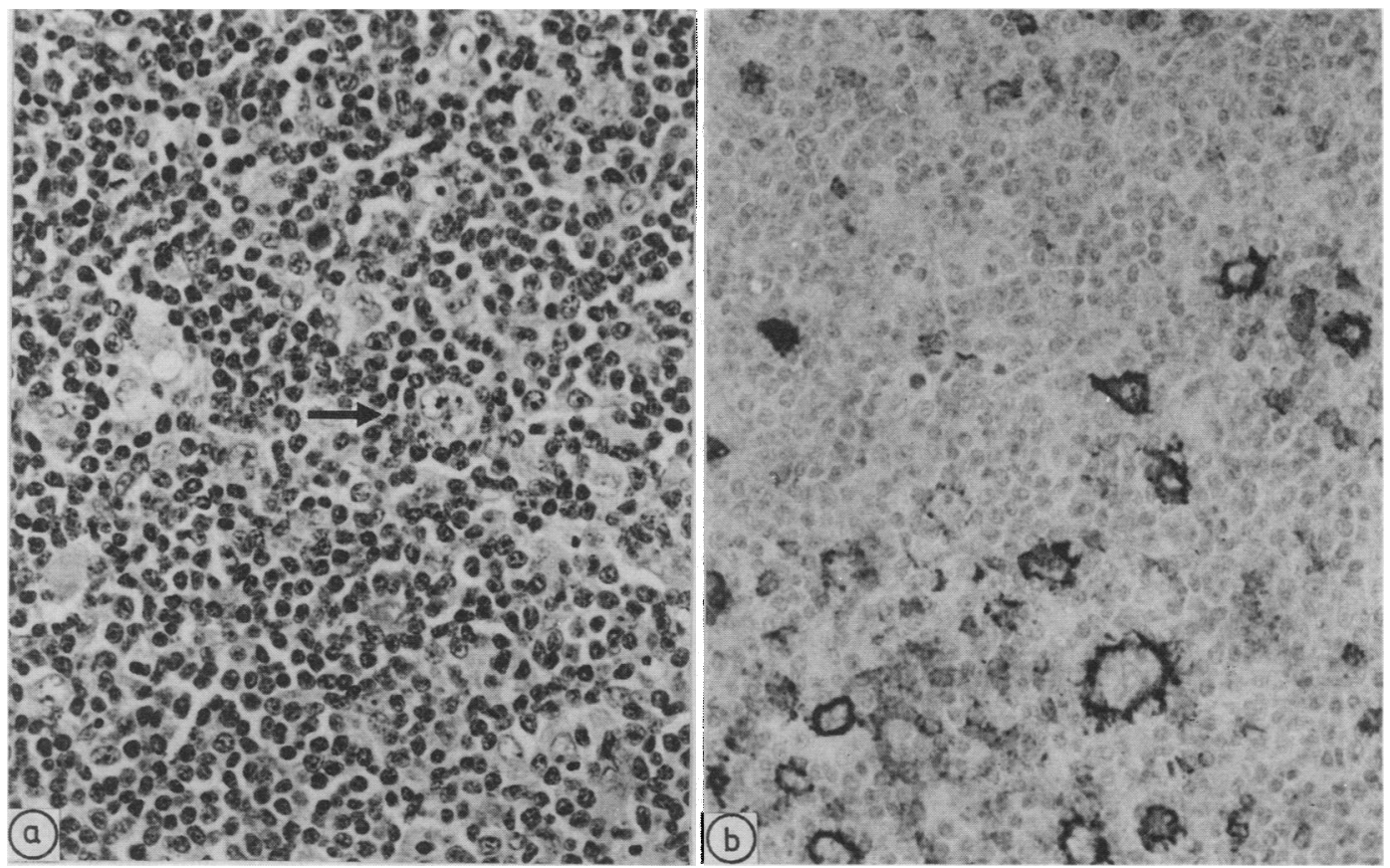

Fig 4a Lymphocyte and histiocyte diffuse Hodgkin's disease with sheets of small lymphocytes and scattered histiocytes, together with occasional large lymphocyte and histiocyte Reed-Sternberg cells (arrow). (Haematoxylin and eosin.)

Fig 4b Same case as in fig 4a stained with L26. Large lymphocyte and histiocyte cells are highlighted by antibody. (Immunoperoxidase.) 


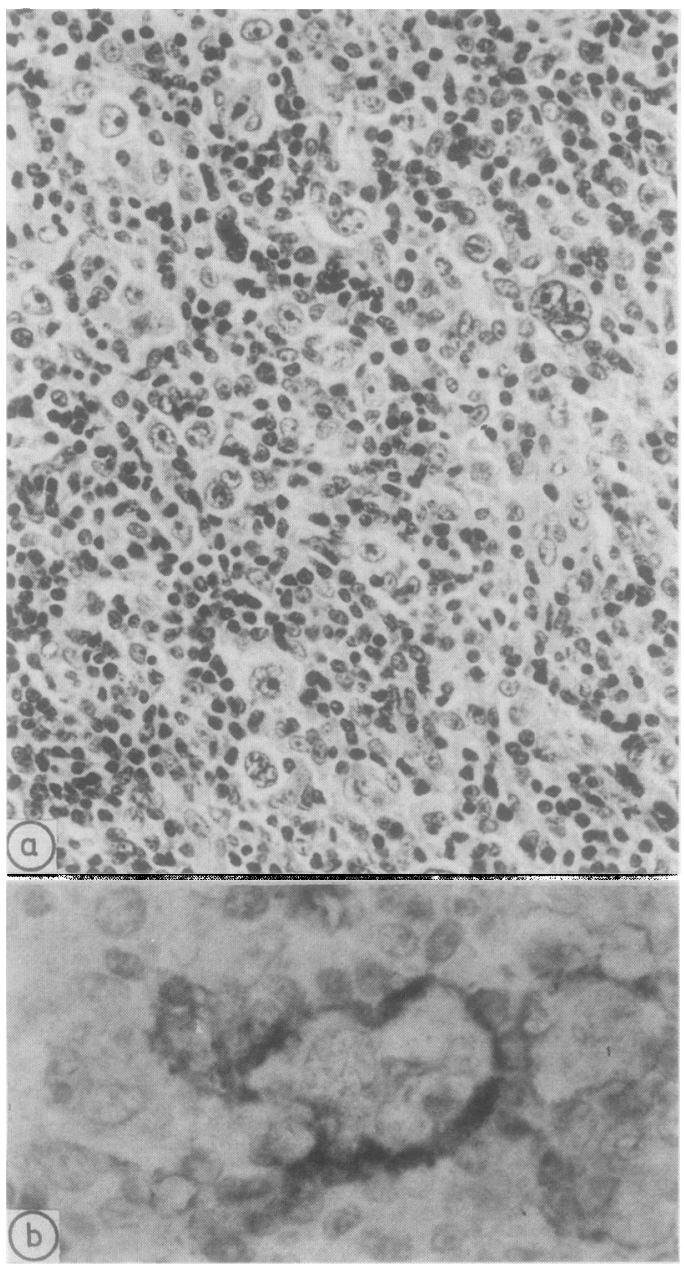

Fig 5a Mixed cellularity Hodgkin's disease. Multinucleated Reed-Sternberg cells and large mononuclear Hodgkin's cells are scattered in a background of lymphocytes, plasma cells, and eosinophils. Note that many background lymphocytes are medium sized with conspicuous nucleoli. (Haematoxylin and eosin.)

Fig 5b High power detail of Reed-Sternberg cells from same case as fig 5a, stained with L26. (Immunoperoxidase.)

\section{Hodgkin's disease}

Staining reactions in the 27 cases of Hodgkin's disease are detailed in table 3. Two notable features were observed. Firstly, Reed-Sternberg cells in nine cases gave strong surface membrane staining with L26. In both cases of lymphocyte and histiocyte predominant subtype all of the Reed-Sternberg cells and their variants were recognised (fig 4). In two cases of mixed cellularity subtype (fig 5) and one case of nodular sclerosing subtype all of the Reed-Sternberg cells were recognised, while in four cases of mixed cellularity and one case of nodular sclerosing subtype less than $50 \%$ of Reed-Sternberg cells and mononuclear Hodgkin's cells were stained. Secondly, L26 highlighted scattered blast cells in all cases of mixed cellularity, and to a lesser extent, nodular sclerosing Hodgkin's disease. These immunoreactive lymphocytes had medium sized round to oval nuclei with between one to four small nucleoli and a moderate amount of cytoplasm. Unlike the Reed-Sternberg cells, these B blasts were reactive with anti-immunoglobulins MB1, MB2, $\mathrm{KiB} 3,4 \mathrm{~KB} 5$ and $\mathrm{LN} 1$ in paraffin sections.

\section{Discussion}

The range of monoclonal antibodies providing phenotypic data on malignant lymphoma in routinely processed tissue has recently expanded. Of greatest value in diagnosis are those antibodies capable of assigning a $\mathrm{T}, \mathrm{B}$, or macrophage phenotype, most of which identify lineage restricted moieties of leucocyte common antigen. Broad panels of these reagents combined with anti-immunoglobulins and nonphenotype associated reagents now permit accurate phenotyping of malignant lymphoma in routinely processed tissue. ${ }^{8-1021}$

Antibodies identifying lineage restricted leucocyte common moieties bind to epitopes derived by variable? splicing of the pre-mRNA. Thus members of the CD45R cluster ${ }^{12}$ and $M B 1^{3}$ recognise $B$ lymphocytes and some B progenitors, while UCHLl recognises T lymphocytes, macrophages, and myeloid cells. ${ }^{22} 23$ None of these reagents is entirely specific, however, as the B cell related antibodies recognise a proportion of normal and neoplastic $T$ cells ${ }^{1289}$ and similarly, UCHLl has been noted to stain sporadic cases of $B$ cell lymphoma. ${ }^{10}$ Two further $\mathrm{T}$ cell related antibodies $\mathrm{MT1}^{3}$ and $\mathrm{L60}^{24}$ are closely related to this leucocyte common restricted group and have also been shown to react with some normal B lymphocytes and a proportion of cases of $B$ cell lymphoma. ${ }^{1024}$ As we have shown in this study, where a tumour exhibits cross lineage reactivity it usually occurs with more than one of these reagents.

Antibodies $\mathrm{LN}^{4}{ }^{4}$ and $\mathrm{MB}^{5}$ differ from the leucocyte common group by recognising a wide range of non-lymphoid tissues in addition to B lymphocytes. In lymphoid tissue immunoreactivity with LN1 is restricted to subsets of $B$ cells ${ }^{410}$ whereas MB2 is a sensitive pan-B reagent. ${ }^{510}$ LN1 exhibits little cross lineage reactivity but MB2 does bind to some $\mathrm{T}$ cell lymphomas. ${ }^{5}$

A recent addition to the range of antibodies to fixation resistant antigens is $\mathrm{KiB3} .{ }^{25}$ The antigen 
identified is restricted to lymphoid cells and is found on mature B lymphocytes, with the notable exception of splenic marginal zone cells. ${ }^{13}$ As we have shown in this study some reactivity with $\mathrm{T}$ cell lymphoma is also observed with this antibody.

In spite of the drawbacks with many of these antibodies, a confident and reliable immunophenotypic diagnosis can be established in most cases of nonHodgkin's lymphoma, provided that a broad panel of antibodies is used..$^{91021}$

In this study we have clearly shown that it is possible to show reliably the $B$ cell nature of nonHodgkin's lymphoma in routinely fixed and wax embedded tissue using L26. With the exception of common acute lymphoblastic leukaemia and malignant lymphoma plasmacytic, neoplastic cells in all instances of B cell lymphoma, including those reactive with MT1, were stained by L26. Furthermore, we have recently encountered a case of B cell lymphoma (malignant lymphoma immunoblastic) reactive with UCHL1, and even in this instance L26 staining was positive. Among our $\mathrm{T}$ cell lymphomas which cross reacted with leucocyte common $B$ cell related antibodies or MB2, in only one case were the neoplastic cells reactive with $\mathrm{L} 26$. This expression of a B cell antigen by a $\mathrm{T}$ cell neoplasm is interesting. Rare instances of well characterised $T$ cell lymphoma giving aberrant reactivity with $B$ cell restricted antibodies have been reported, and these were all large cell $\mathrm{T}$ cell neoplasms. ${ }^{26}{ }^{27}$ With the exception of such unusual cases, L26 can be regarded as a specific marker of B cell differentiation in non-Hodgkin's lymphoma. Both its sensitivity and greater specificity compared with that of the other B cell related markers cited here permit its use as a single reagent. Thus recourse to a broader panel of B cell related antibodies is only rarely required. Although B cell specific, the L26 antigen is not expressed early in B cell ontogeny, ${ }^{13}$ being absent in pre-B acute lymphoblastic leukaemia and common acute lymphoblastic leukaemia. It is therefore advisable to use L26 in combination with a CD45R as this will increase the diagnostic yield in primitive $B$ cell neoplasms.

The reactivity of L26 with Reed-Sternberg cells is noteworthy. The strong reactivity observed in lymphocyte and histiocyte predominant Hodgkin's disease supports the view of many workers that this subtype is indeed a B cell proliferation. ${ }^{28} 29$ In paraffin sections lymphocyte and histiocyte cells differ from typical Reed-Sternberg cells in their reactivity with leucocyte common and B cell restricted leucocyte common antibodies, ${ }^{21} \mathrm{MB}^{5}, \mathrm{LN} 1,{ }^{4}$ and $\mathrm{KiB} 3{ }^{25}$ The observation that some Reed-Sternberg cells in the mixed cellularity and nodular sclerosing subtypes of Hodgkin's disease may express the L26 antigen is in keeping with the work of other groups who have used B1 (CD20) in cryostat sections. ${ }^{27}$ Together with CD20, CD19, CD21, CD22, and CD23, B cell antigens have all been reported in Reed-Sternberg cells $^{2730}$ and have been cited as evidence that these subtypes of Hodgkin's disease are also B cell derived. The histogenesis of the Reed-Sternberg cell, however, remains enigmatic, and $T$ cell related antigens have also been found both in isolation and in combination with B cell antigens in the same cells. ${ }^{30}$ Currently the molecular biological data are equally ambiguous, with different groups of workers showing $B$ cell and $T$ cell specific genetic rearrangements. ${ }^{31-33}$ For practical purposes, morphological criteria are adequate for the diagnosis of Hodgkin's disease, and reactivity of Reed-Sternberg cells with L26 should not lead to confusion with B cell non-Hodgkin's lymphoma. Where the morphological considerations are in doubt the use of CD15, anti- $\alpha_{1}$ antitrypsin, antiimmunoglobulins, and the leucocyte common (CD45) or leucocyte common, restricted reagents will be of help in the differential diagnosis. ${ }^{21}$

In conclusion, we have shown that L26 offers a more reliable indication of $B$ cell phenotype in routinely processed cases of non-Hodgkin's lymphoma than is currently possible with restricted leucocyte common antibodies LN1 or MB2. The search for other reagents to well characterised cluster determinants or to individual molecular weight moieties of the leucocyte common molecule, as epitomised by UCHL1, will further enhance the diagnostic accuracy of malignant lymphoma in routinely fixed and processed tissues.

We thank Mr K Miller, Rosemary Bains, and Lisa Happerfield, for their excellent technical help. We also thank Professor MR Parwaresch for providing $\mathrm{KiB} 3$ and Dr DY Mason for providing 4KB5. This work was supported by a grant from the North East Thames Regional Health Authority.

\section{References}

I Cobbold S, Hale G, Waldmann H. Summary of studies on the non-lineage, LFA-1 family, and leucocyte common antigen panel of antibodies. In: McMichael AJ, Beverley PCL, Crumpton M, et al, eds. Leucocyte typing 3. Oxford: Oxford University Press, 1987.

2 Dalchau R, Fabre JW. Identification with a monoclonal antibody of a predominant B lymphocyte-specific determinant of the human leukocyte common antigen. Evidence for structural and possible functional diversity of the human leukocyte common molecule. J Exp Med 1981;153:753-65.

3 West KP, Warford A, Fray L, Allen M, Campbell AC, Lauder I The demonstration of B-cell, T-cell and myeloid antigens in paraffin sections. J Pathol 1986;150:89-101.

4 Epstein AL, Marder RJ, Winter JN, Fox RI. Two new monoclonal antibodies ( $\mathrm{LN}-1, \mathrm{LN}-2)$ reactive in B5 formalin-fixed paraffin-embedded tissues with follicular center and mantle 
zone human B lymphocytes and derived tumors. $J$ Immunol 1984;133:1028-36.

5 Hall PA, d'Ardenne AJ, Butler MG, Habeshaw JR, Stansfeld AG. New marker of B lymphocytes, MB2: comparison with other lymphocyte subset markers active in conventionally processed tissue sections. J Clin Pathol 1987;40:151-6.

6 Epenetos AA, Bobrow LG, Adams TE, Collins CM, Isaacson PG, Bodmer WF. A monoclonal antibody that detects HLA-D region antigen in routinely fixed, wax embedded sections of normal and neoplastic lymphoid tissues. J Clin Pathol 1985;38:12-7.

7 Marder RJ, Variakojis D, Silver J, Epstein AL. Immunohistochemical analysis of human lymphomas with monoclonal antibodies to $B$ cell and Ia antigens reactive in paraffin sections. Lab Invest 1985;52:497-504.

8 Salter DM, Krajewski AS, Dewar AE. Immunohistological staining of non-Hodgkin's lymphoma with monoclonal antibodies specific for the leukocyte common antigen. J Pathol 1985; 146:345-53.

9 Norton AJ, Isaacson PG. Immunocytochemical study of T-cell lymphomas using monoclonal and polyclonal antibodies effective in routinely fixed wax embedded tissues. Histopathol 1986;10:1243-60.

10 Norton AJ, Isaacson PG. Detailed phenotypic analysis of B-cell lymphoma using a panel of antibodies reactive in routinely fixed wax embedded tissue. Am J Pathol 1987;128:225-40.

11 Ishii Y, Takami T, Yuasa H, Takei T, Kikuchi K. Two distinct antigen systems in human $\mathrm{N}$ lymphocytes: identification of cell surface and intracellular antigens using monoclonal antibodies. Clin Exp Immunol 1984;58:183-92.

12 Takei T, Kokai Y, Kikuchi K. Six distinct antigen systems of human $B$ cells as defined by monoclonal antibodies. In: Reinherz EL, Haynes BF, Nadler LM, Bernstein ID, eds. Leukocyte typing II. Berlin: Springer-Verlag, 1986:109-19.

13 Ling NR, MacLennan ICM, Mason DY. Analysis of the B cell and plasma cell panels. In: McMichael AJ, Beverley PCL, Crumpton M, et al, eds. Leucocyte typing 3. Oxford: Oxford University Press, 1987.

14 Stashenko P, Nadler LM, Hardy R, Schlossman SF. Characterisation of a human B lymphocyte-specific antigen. J Immunol 1980;125:1678-85.

15 Lennert K, Mohri M, Stein H, Kaiserling E, Müller-Hermelink HK. Malignant lymphomas other than Hodgkin's disease. Heidelberg: Springer-Verlag, 1978.

16 Lukes RJ, Butler JJ. The pathology and nomenclature of Hodgkin's disease. Cancer Res 1966;26:1063-81.

17 Stansfeld AG. Peripheral T-cell lymphomas. In: Stansfeld AG, ed. Lymph node biopsy interpretation. London: Churchill Livingstone, 1985:300-29.

18 Nadler LM. B cell/Leukaemia panel workshop: summary and comments. In: Reinherz EL, Haynes BF, Nadler LM, Bernstein ID, eds. Leukocyte typing II. Berlin: Springer-Verlag, 1986:3-43.

19 Guesdon JL, Ternynck T, Avrameas S. The use of avidin-biotin interaction in immunoenzymatic techniques. $J$ Histochem Cytochem 1979;27:1131-9.
20 Ramsay AD, Smith WJ, Earl HM, Souhami RL, Isaacson PG Adult T-cell lymphomas: a clinicopathological study of eighteen cases. J Pathol 1987;152:63-76.

21 Norton AJ, Isaacson PG. The diagnosis of malignant lymphoma using monoclonal antibodies reactive in routinely fixed wax embedded tissue. $J$ Pathol 1987;151:183-4.

22 Smith SH, Brown MH, Rowe D, Callard RE, Beverley PCL. Functional subsets of human helper-inducer cells defined by a new monoclonal antibody, UCHL1. Immunology 1986;58: 63-70.

23 Norton AJ, Ramsay AD, Smith SH, Beverley PCL, Isaacson PG Monoclonal antibody (UCHL1) that recognises normal and neoplastic $\mathrm{T}$ cells in routinely fixed tissues. $J$ Clin Pathol 1986;39:399-405.

24 Wieczorek R, Bindl J, Knowles DM. Monoclonal antibody L60 preferentially detects neoplastic $T$ cells in formalin-fixed, paraffin-embedded tissue sections. Lab Invest 1987;56:86A.

25 Hansmann ML, Wacker HH, Radzun HJ. Paragranuloma is a variant of Hodgkin's disease with a predominance of B-cells. Virchows Arch (Pathol Anat) 1986;409:171-81.

26 Stein H, Mason DY, Gerdes J, et al. The expression of the Hodgkin's disease associated antigen $\mathrm{Ki}-1$ in reactive and neoplastic lymphoid tissue: evidence that Reed-Sternberg cells and histiocytic malignancies are derived from activated lymphoid cells. Blood 1985;66:848-58.

27 Pallesen G. Immunohistological analysis of tissue specificity of the fifty-two workshop anti-B lymphocyte monoclonal antibodies. In: Reinherz EL, Haynes BF, Nadler LM, Bernstein ID, eds. Leukocyte typing II. Berlin: Springer-Verlag, 1986: 277-88.

28 Timens W, Visser L, Poppema S. Nodular lymphocyte predominance type of Hodgkin's disease is a germinal center lym phoma. Lab Invest 1986;54:457-61.

29 Pinkus GS, Said JW. Hodgkin's disease, lymphocyte predomi nance type, nodular-a distinct entity? Unique staining profie for lymphoma and histiocyte variants of Reed-Sternberg cells defined by monoclonal antibodies to leukocyte common antis gen, granulocyte-specific antigen, and B-cell specific antigen: Am J Pathol 1985;118:1-5.

30 Stein H, Gerdes J, Lemke H, Mason DY. Evidence of SternbergReed cells being derived from activated lymphocytes. In: Neth R, Gallo RC, Greaves MF, Janka G, eds. Modern trends in human leukaemia VI. Berlin: Springer-Verlag, 1985:441-4.

31 Linch DC, Jones HM, Berliner N, et al. Hodgkin-cell leukaemia of B-cell origin. Lancet 1986; ;:78-80.

32 Weiss LM, Strickler JG, Hu E, Warnke RA, Skiar J. Immunoglobulin gene rearrangements in Hodgkin's disease. Hum Pathol 1986;17:1009-14.

33 Griesser H, Feller A, Lennert K, Minden M, Mak TW. Rearrangement of the $\beta$ chain of the $T$ cell antigen receptor and immunoglobulin genes in lymphoproliferative disorders. J Clin Invest 1986;78:1179-84.

Requests for reprints to: Dr AJ Norton, Department of Histopathology, University College and Middlesex Medical School, University Street, London WCIE 6JJ, England. 